\title{
Monitoring and Evaluation of Physical Facilities of the Bulacan State University: Basis for the Development of Facility Management Policy Guide
}

\author{
Romulo B. Panotes \\ College of Engineering, Bulacan State University, City of Malolos, Philippines \\ Email: romy panotes@yahoo.com
}

Received 8 June 2015; accepted 25 June 2015; published 2 July 2015

Copyright (C) 2015 by author and OALib.

This work is licensed under the Creative Commons Attribution International License (CC BY). http://creativecommons.org/licenses/by/4.0/

C) (i) Open Access

\section{Abstract}

The objective of this study is to analyze the extent of monitoring and evaluation of the physical facilities of Bulacan State University as basis for the development of a facility management policy guide. The respondents of the study were members of the administrative and academic council and all of the support staff in the university. Findings revealed that the administrators assessed that the physical facilities, Buildings, Classrooms, Library, Laboratory, Assembly and Athletic Facilities, Medical/Dental Clinic and Student Center are "Monitored to Moderate Extent". However, the same group of respondents assessed that the physical facilities inside the Offices, Staff and Function rooms and Food Services/Canteen are "Monitored to a Great Extent". Likewise, the faculty- respondents assessed that the physical facilities in the $\mathbf{1 0}$ areas of concern is "Monitored to a Moderate Extent". On the contrary, the support staff-respondents assessed that the physical facilities in the ten areas of concern are "Monitored to a Great Extent". In sum, the study found that there are significant differences among the perceptions of the administrators, faculty members and support staff on the extent of monitoring and evaluation of physical facilities of the Bulacan State University. Based on these assessments, a facility management policy guide was proposed to help employees of the Bulacan State University to have a better understanding of the aims and goals of facility management. It is intended to answer questions which pertain to the rules and regulations that govern the operation and maintenance of each section and shop.

\section{Keywords}

Monitoring, Evaluation, Physical Facilities, Facility Management, Bulacan State University

Subject Areas: Industrial Engineering, Mechanical Engineering 


\section{Introduction}

Most people believe that an adequate and well-maintained school facility contributes significantly to student learning. However, improper use of facilities can happen anytime and anywhere but to a great extent, they are controllable and can be prevented. If only everyone in the academic community believes in this statement, then it is assured that the institution is off a good start.

Well-maintained physical facilities are a basic requirement that enables people in the organization to maximize their potential to achieve goals and objectives. Physical facilities are both a public and individual responsibility since it relies on corporate initiative to use it accordingly. A comprehensive monitoring and evaluation of physical facilities inside the campus is critical in providing an effective school environment. Governmental institutions from the national down to community levels are actively engaged in maintaining and preserving their facilities. A monitored and well-evaluated facility is a major prerequisite for effective teaching and learning.

In view of this, emphasis should be placed upon the development of sound attitudes in maintaining university physical facilities. The effectiveness of instruction can be measured in terms of performance. Factual knowledge concerning facilities is very essential and such knowledge can be translated into caring habits. The formulation and subsequently the implementation of a facility management can be established through the proper manipulation of tools, machines, and should be manned by facility-conscious individuals who perform operations and processes.

Bulacan State University is a state-funded institution of higher learning established in 1904 by virtue of Act 74 of the Philippine Commission of 1901 as an intermediate school set up by the American regime. It was converted into a chartered state university in 1993 by virtue of Republic Act 7665. Its main campus is located in City of Malolos, Bulacan province, Philippines. It has four satellite campuses in the province (Bustos Campus in Bustos, Sarmiento campus in San Jose del Monte, Meneses campus in Bulakan, Hagonoy and Pulilan Campus in Pulilan). It also has an international campus in Hong Kong that offers graduate and collegiate degree courses.

The university is mandated to provide higher professional/technical training and promote research, advanced studies and progressive leadership. It has been identified by the Commission on Higher Education (CHED) as one of the Centers for Excellence and Development institutions in the country [1] and one of the Training Centers nationwide for teachers pursuing education in areas beyond their specialization [2]. In the Main campus alone, more than 20,000 students are situated whereby all use the various facilities and equipment. It is for this reason that one of the major purposes of a facility management is to guide, maintain and manage the physical facilities of Bulacan State University. An organized facility management through a cooperative activity among the school administrators, the faculty, non-teaching personnel and the students can help a lot. Facility education should be looked upon as valuable knowledge that is measurable in which reduces the facility deterioration.

This fueled the burning desire of the researcher to investigate the policy of monitoring and evaluation of the physical facilities of the Bulacan State University (BulSU) as basis for the development of a facility management enhancement program. The results of this investigation may help the BulSU administration in enhancing their physical plant and facilities, thereby improving the delivery of quality education through efficiency and effectiveness.

\section{The Research Problem}

The general problem of this study is "How may the monitoring and evaluation of the physical facilities of the Bulacan State University (BulSU) be analyzed as basis for the development of a facility management program?”

Specifically, this study sought answers to the following questions:

1) What is the extent of monitoring and evaluation of the physical facilities as perceived by the administration, faculty members, and support staff?

2) Are there significant differences among the perceptions of the administration, faculty members, and support staff on the extent of monitoring and evaluation of the physical facilities?

3) What facility management policy guide may be proposed to enhance the monitoring and evaluation of physical facilities of BulSU?

\section{Methodology}

The framework that guided this study is depicted in the form of paradigm shown in Figure 1. This study followed 


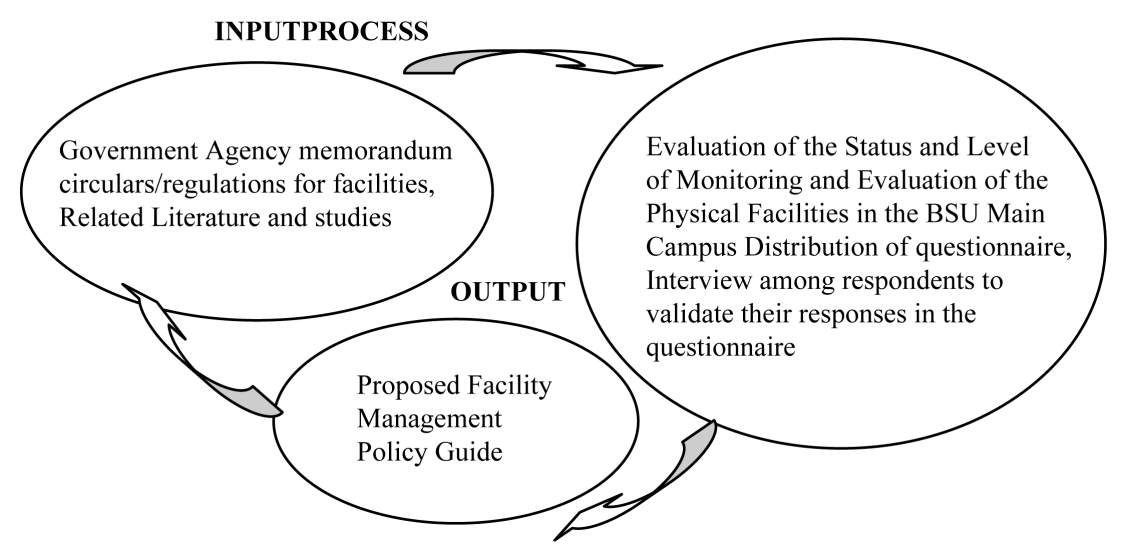

Figure 1. Conceptual framework.

the input, process and output (IPO) model.

The INPUTS of the study consist of various government agency memorandum circulars/regulations for facilities and equipment, reviewed related literature and studies. The PROCESS of the study consists of evaluation of the status and level of monitoring and evaluation of the physical facilities in the BSU Main Campus, the distribution of questionnaire and unstructured interviews among respondents to validate their responses in the questionnaire. The OUTPUT of the study proposed facility management policy guide.

The study utilized the descriptive method of research. A descriptive study describes and interprets. It relates to conditions or relationships, opinions held and processes going on, effects that are evident or trends that are developing. It is primarily concerned with the present, although it often considers past events and influences as they relate to current conditions [3].

The respondents of the study were the administrators and faculty members who are members of both the administrative council and academic council as well as the support staff from the general services office. They are chosen as such since they had experienced on the monitoring and evaluation of facilities in BSU Main Campus. These three groups of respondents were requested to accomplish the validated survey instrument to gather the needed information.

The data gathering technique used in this study is the survey method using a standardized questionnaire to gather data and information from the subject respondents. The validated instruments of the Accrediting Agency of Chartered Colleges and Universities in the Philippines (AACCUP) on the areas of physical plant and facilities, library and laboratories were used in data gathering. However, this instrument was slightly modified by the researcher to cover all other areas not covered by the present AACCUP instrument such as athletic, medical and dental, student center and the like.

The modified questionnaire was validated by a panel of experts who are facility engineers and faculty members of the College of Engineering who were involved in the maintenance services of the infrastructures. Problems that were descriptive in nature were answered using frequency, mean and standard deviation. Descriptive statistics described the average or central location of the data, the dispersion of the data, or the association among the variables of the study. Descriptive statistics also indicated the extent of data set from the expected normal distribution. Analysis of Variance (ANOVA) was used to ascertain the differences of perception of the respondents in this study. Finally, the 5-point Likert scale presented below was used in the survey instrument to convey the corresponding range and descriptive ratings.

\begin{tabular}{cc}
\hline Range & Level of Monitoring \\
\hline $4.6-5.0$ & Monitored to Very Great Extent (MVGE) \\
$3.6-4.5$ & Monitored to Great Extent (MGE) \\
$2.6-3.5$ & Monitored to a Moderate Extent (MME) \\
$1.6-2.5$ & Monitored to a Fair Extent (MFE) \\
$1.0-1.5$ & Monitored to a Little Extent (MLE) \\
\hline
\end{tabular}




\section{Result and Discussion}

This chapter presents, analyses, and interprets the gathered data for the purpose of ascertaining the extent of monitoring and evaluation of physical facilities of the Bulacan State University as basis for the development of a facility management guide. For better understanding and interpretation of the data, the presentation was done part by part in accordance to the specific problems presented earlier.

\subsection{Extent of Monitoring and Evaluation of Physical Facilities of Bulacan State University}

\subsubsection{Campus}

As reflected on Table 1, the overall mean of 3.50, the support staff-respondents assessment that the monitoring of the physical facilities inside the campus is "Monitored to a Great Extent". On the other hand, both the administrators and faculty assessed that the monitoring of the physical facilities in the campus is only "Monitored to a Moderate Extent”, as evidenced by the obtained means of 3.08 and 3.02, respectively.

The covered walks garnered the highest mean rating of 3.65 and 3.61 in the perception of the administrators and faculty members, respectively. This mean rating has an equivalent verbal interpretation of "Monitored to a Great Extent". This means that both the administrators as well as faculty members viewed the University in monitoring the covered walks for their constituents. On the other hand, the support staff gave their highest ratings on the provision of security stations/guard house as evidenced by the obtained mean of 3.86, interpreted as "Monitored to a Great Extent".

It is inherent for each university must strive to monitor working environments inside the campus that minimize the risk of injury or illness for employees, students and the public; continuously improves operations, with the goal of meeting or exceeding authorized and applicable environmental, health and safety regulations, rules, policies, or voluntary standards [4].

\subsubsection{Buildings}

The overall mean of 3.73 indicates the support staff-respondents assessed that the monitoring of physical facilities of the building is a "Monitored to a Great Extent". On the other hand, both the administrators and faculty assessed that the level of implementation of monitoring and evaluation practices inside the buildings "Monitored to a Moderate Extent", as evidenced by the obtained means of 3.12 and 2.93, respectively as shown.

Further examination that the different perceptions of the three groups of respondents regarding their highest ratings. According to the administrators, the "Roof, ceiling, walls, floors" garnered the highest mean rating of

Table 1. Mean distribution of the extent of monitoring and evaluation of physical facilities.

\begin{tabular}{lcccccc}
\hline \multicolumn{1}{r}{ Ten Areas } & \multicolumn{2}{c}{ Administrator } & \multicolumn{2}{c}{ Faculty } & \multicolumn{3}{c}{ Staff } \\
\cline { 2 - 7 } & Mean & VI & Mean & VI & Mean & VI \\
\hline 1) Campus & 3.08 & MME & 3.02 & MME & 3.50 & MGE \\
2) Buildings & 3.12 & MME & 2.93 & MME & 3.73 & MGE \\
3) Classrooms & 3.10 & MME & 3.02 & MME & 3.73 & MGE \\
4) Library & 3.41 & MME & 3.28 & MME & 3.92 & MGE \\
5) Laboratory & 3.39 & MME & 3.07 & MME & 3.78 & MVGE \\
6) Offices, Staff and Function Rooms & 3.57 & MGE & 3.22 & MME & 3.79 & MGE \\
7) Assembly and Athletic Facilities & 3.17 & MME & 2.96 & MME & 3.68 & MGE \\
8) Medical and Dental Clinic & 3.39 & MME & 3.24 & MME & 3.84 & MGE \\
9) Student Center & 3.16 & MME & 3.24 & MME & 3.81 & MGE \\
10) Food Service/Canteen & 3.52 & S & 3.37 & MME & 3.90 & MGE \\
\hline
\end{tabular}


3.31, interpreted as "Monitored to a Moderate Extent". However, in the perceptions of the faculty, "Pest control facilities obtained the highest mean rating of 3.58, interpreted as "Monitored to a Great Extent". On the other hand, the support staff gave "Fire alarm system/s their highest rating of 4.14, interpreted as "Monitored to a Great Extent”.

Protecting the health, safety, and welfare (HSW) of building occupants has expanded beyond disease prevention and nuisance control to include mental as well as physical health and protecting the ecological health of a place through the creation of spaces that enable delight and the realization of human potential [5].

\subsubsection{Classrooms}

It can be gleaned from Table 1 that according to the support staff, the item referring to tables and chairs garnered the highest mean value of 3.96, interpreted as "Monitored at a Great Extent". On the other hand, the faculty members gave their highest ratings on the item referring to Floors with a mean value of 3.24, interpreted as "Monitored at a Moderate Extent". Meanwhile the administrators gave ventilation system, which is "Monitored at a Moderate Extent" their highest mean rating of 3.24 with a verbal equivalent of "Monitored at a Moderate Extent”.

As reflected by the overall mean of 3.73, the support staff-respondents assessed that there is a "Monitored at a Great Extent" of monitoring and evaluation inside the classrooms. On the other hand, both the administrators and faculty assessed that there is only a "Monitored at a Moderate Extent" of monitoring and evaluation inside the classrooms, as evidenced by the obtained means of 3.10 and 3.02, respectively.

\subsubsection{Library}

As reflected by the overall mean of 3.92, the support staff-respondents assessed that there is monitoring of physical facilities of Bulacan State University inside the libraries, that is "Monitored at a Great Extent". On the other hand, both the administrators and faculty assessed that there is only a "Monitored at a Moderate Extent" of monitoring and evaluation of physical facilities in terms of the library variable, as evidenced by the obtained means of 3.41 and 3.28 , respectively.

Further item referring to "File cabinet" was given a mean rating of 4.14 and 3.73, with verbal interpretation of "Monitored at a Moderate Extent" by the support staff and administrators, respectively. On the other hand, the faculty members gave their highest rating on the item referring to good lighting fixtures, with an obtained mean value of 3.59, interpreted as "Monitored at a Moderate Extent".

\subsubsection{Laboratory}

As shown in the tabular values, the overall mean of 3.78 indicates that the support staff respondents assessed that there is a "Monitored at a Very Great Extent" of monitoring and evaluation of physical facilities inside the laboratories. On the other hand, both the administrators and faculty assessed that there is only a "Monitored at a Moderate Extent" of monitoring and evaluation of physical facilities inside the laboratories, as evidenced by the obtained means of 3.39 and 3.07, respectively.

Further examination both the administrators and staff gave favorable ratings to the item referring to the laboratories lighting system as evidenced by the obtained mean values of 3.51 and 4.04, respectively. On the other hand, the faculty members viewed differently as they rated the Multimedia equipment of the laboratories with their highest mean rating of 3.28, interpreted as "Monitored at a Moderate Extent".

Modern laboratories, particularly in academia, often have contiguous spaces that include wet laboratories, computer laboratories, instruments, write-up spaces, office areas, and other spaces with varying degrees of chemical use and hazards. Maintaining a positive safety culture and at the same time meeting the safety and comfort needs of laboratory personnel are challenging under these circumstances [6].

\subsubsection{Offices, Staff and Function Rooms}

Results show that both the administrators and the support staff-respondents assessed that there is a "Monitored at a Great Extent" of monitoring of physical facilities inside the offices, staff and function rooms as reflected by the overall mean of 3.57 and 3.79, respectively. On the other hand, the faculty assessed that there is only a "Monitored at a Moderate Extent" of monitoring of physical facilities inside the offices, staff and function rooms, as evidenced by the obtained mean of 3.22 .

Values reveal that all the administrators, faculty and staff gave high ratings on "Ventilation" as evidenced on 
the mean values of 3.66, 2.55 and 4.04, respectively. These findings show that the respondents viewed that the offices, staff and function room are "Monitored at a Great Extent" in the sense that these rooms were clean and ventilated. This finding is important since adequate provisions should be made for administrative offices, faculty rooms and reception areas, where needed. Facilities management is an integral part of the overall management of the school. The actualization of the goals and objectives of education require the provision, maximum utilization and appropriate management of the facilities. Furthermore, advances in science and technology, necessitate that the school manager should adopt modern methods of facilities management. This will improve the quality of teaching and learning [7].

\subsubsection{Assembly and Athletic Facilities}

It can be gleaned from the table that both the administrators (3.31) as well as the faculty members (3.18) gave their highest ratings on the same two items referring to the assembly and athletic facilities having adequate bench and appropriate floorings. This shows that these respondents have the same perception towards these characteristics of these facilities. Meanwhile, the support staff gave "Athletic and Military facility" their highest mean rating of 4.02, interpreted as "Monitored at a Great Extent".

Results show that both the administrators and the faculty-respondents assessed that there is a "Monitored at a Moderate Extent" of monitoring of physical facilities in the assembly and athletic facilities as reflected in the overall mean of 3.17 and 2.96, respectively. On the other hand, the support staff-respondents assessed that there is a "Monitored at a Great Extent" of physical facilities inside the assembly and athletic facilities, as evidenced by the obtained mean value of 3.68 .

People who are to undertake reviews of facilities and equipment and who are involved in the management of such, also need to be adequately trained in risk assessment in order for them to be adequately carried out and safe practice systems to be brought in where required.

\subsubsection{Medical and Dental Clinic}

As reflected by the overall mean of 3.84, the support staff-respondents assessed that there is a "Monitored at a Great Extent" of monitoring of physical facility inside the medical and dental clinic. On the other hand, both the administrators and faculty assessed that there is only a "Monitored at a Moderate Extent" of monitoring of physical facilities inside the clinics, as evidenced by the obtained means of 3.39 and 3.24, respectively.

"The dental section is equipped and properly maintained with first aid kits" were given a mean rating of 3.67 and 3.73, with verbal interpretation of "Monitored at a Great Extent" by administrators and faculty, respectively. On the other hand, the support staff gave their highest rating on the item referring to the disposal system, with an obtained mean value of 4.04, interpreted as "Monitored at a Great Extent".

\subsubsection{Student Center}

As shown in the tabular values, the overall mean of 3.81 indicates the support staff-respondents assessed that there is a "Monitored at a Great Extent" of monitoring of physical facilities in terms of student center. On the other hand, both the administrators and faculty assessed that there is only a "Monitored at a Moderate Extent" of monitoring of physical facilities in terms of student center, as evidenced by the obtained means of 3.16 and 3.24, respectively.

According to the administrators, faculty and support staff-respondents, “Comfort rooms” garnered the highest mean ratings of 3.40 (Monitored at a Moderate Extent), 3.39 (Monitored at a Moderate Extent) and 3.98 (Monitored at a Great Extent), respectively.

The University's student center must provide designs in accordance with good practice as well as applicable building, fire, safety, and health codes and regulations. This is very important since a direct relationship exists between the quality of school facilities provided and the quality of the products of the school. The physical environment of a school is a major determining factor in the attainment of its objectives [8].

\subsubsection{Food Services/Canteen}

It can be gleaned from the table that according to the support staff, the first item referring to the institution having food storage garnered the highest mean value of 4.06, interpreted as "Monitored at a Great Extent". On the other hand, both the administration and faculty members gave their highest ratings on the item referring to Dining tables and chairs accommodate the students, with a means value of 3.64 and 3.53, respectively and both 
interpreted as "Monitored at a Great Extent". These findings show that clean and sanitary food services unit/canteen must be set up and managed effectively. The school canteens should be enjoined to serve balanced yet affordable meals and snacks to the school community for their health and well-being.

As reflected by the overall mean of 3.90, the support staff-respondents assessed that there is a "Monitored at a Great Extent" of monitoring of physical facilities inside the food services/canteens. On the other hand, both the administrators and faculty assessed that there is only a "Monitored at a Moderate Extent" of monitoring of physical facilities inside the food services/canteens, as evidenced by the obtained means of 3.52 and 3.37, respectively.

\subsection{Differences in the Perceptions of the Respondents on the Extent of Monitoring and Evaluation of Physical Facilities in the Bulacan State University}

These results of the study indicate a significant difference in the perceptions of the three groups of respondents on the extent of monitoring and evaluation of physical facilities of Bulacan State University's campus, buildings, classrooms, library, laboratory, offices, staff and function rooms, assembly and athletic facilities, medical and dental clinic, student center, and food services/canteen (Table 2).

In addition, the author also worked on a mathematical model by identifying the dependent and the independent variables and accounted for the nature of non-linearity of some of the variables. In this methodology, General Linear Regression with ANOVA using Minitab 16 Software was used.

$$
\hat{\mathrm{Y}}=\beta_{0}+\beta_{1} \text { Admin }+\beta_{2} \text { Faculty }+\beta_{3} \text { Support Staff }
$$

where: $\hat{Y}=$ Perception

Dependent Variable (Response variable): Perception of each of the respondents

Independent Variable: Categories of the respondents, and

Controlled Variable: Facilities

Null Hypothesis: The categories (Admin, Faculty and Support Staff) have no significant effect on the perceptions of the respondents for each facility. $\beta_{1}=\beta_{2}=\beta_{3}=0$

Alternative Hypothesis: At least one of the categories (Admin, Faculty and Support Staff) has a significant effect on the perceptions of the respondents for each facility.

$$
\beta_{\mathrm{j}} \neq 0 \text { for } \mathrm{j}=1 \text { (Admin), } 2 \text { (Faculty), } 3 \text { (Support Staff) }
$$

Note: If the conclusion is "significant", there is a significant difference between or among the perception of the respondents, which means that the category/categories (Admin, Faculty and Support Staff) has/have signifi-

\begin{tabular}{|c|c|c|}
\hline \multirow{2}{*}{ Variables } & \multicolumn{2}{|c|}{ Analysis of Variance } \\
\hline & $F_{\text {value }}$ & $F_{\text {critical }}$ \\
\hline Campus & 8.875 & \\
\hline Buildings & 20.820 & \\
\hline Classrooms & 13.847 & \\
\hline Library & 14.282 & \\
\hline Laboratory & 17.340 & \\
\hline Offices, Staff and Function Rooms & 13.337 & 3.027 \\
\hline Assembly and Athletic Facilities & 17.005 & \\
\hline Medical and Dental Clinic & 13.349 & \\
\hline Student Center & 13.268 & \\
\hline Food Service/Canteen & 12.842 & \\
\hline Combined Variables & 49.583 & \\
\hline
\end{tabular}
cant effect in the perceptions. Otherwise, the category/categories is/are not different from the other. 
P-value is used to determine the significance. If the P-value is less than 0.05 , the conclusion must be "significant” since the level of significance used is $5 \%$.

\begin{tabular}{|c|c|c|c|}
\hline $\begin{array}{c}\text { Facility and Category } \\
\text { of Respondent }\end{array}$ & P-value & Conclusion & Interpretation \\
\hline $\begin{array}{l}\text { Campus } \\
\text { - Admin } \\
\text { - Faculty } \\
\text { - } \text { Support Staff }\end{array}$ & $\begin{array}{l}0.008 \\
0.006 \\
0.000\end{array}$ & $\begin{array}{l}\text { Significant } \\
\text { Significant } \\
\text { Significant }\end{array}$ & $\begin{array}{l}\hat{\mathrm{Y}}=3.505-0.875 \text { Admin }-0.905 \text { Faculty }-0.682 \text { Support } \\
\text { Each category has a significant effect to the perception which } \\
\text { means there are differences in the perceptions of each category. }\end{array}$ \\
\hline $\begin{array}{l}\text { Building } \\
\text { - } \text { Admin } \\
\text { - } \text { Faculty } \\
\text { - } \text { Support Staff }\end{array}$ & $\begin{array}{l}0.0005 \\
0.0001 \\
0.0000\end{array}$ & $\begin{array}{l}\text { Significant } \\
\text { Significant } \\
\text { Significant }\end{array}$ & $\begin{array}{l}\hat{\mathrm{Y}}=3.875-1.195 \text { Admin }-1.35 \text { Faculty }-0.672 \text { Support } \\
\text { Each category has a significant effect to the perception which } \\
\text { means there are differences in the perceptions of each category. }\end{array}$ \\
\hline $\begin{array}{l}\text { Classrooms } \\
\text { - Admin } \\
\text { - Faculty } \\
\text { - } \text { Support Staff }\end{array}$ & $\begin{array}{l}0.002 \\
0.000 \\
0.000\end{array}$ & $\begin{array}{l}\text { Significant } \\
\text { Significant } \\
\text { Significant }\end{array}$ & $\begin{array}{l}\hat{Y}=3.833-1.056 \text { Admin }-1.2 \text { Faculty }-0.671 \text { Support } \\
\text { Each category has a significant effect to the perception which } \\
\text { means there are differences in the perceptions of each category. }\end{array}$ \\
\hline $\begin{array}{l}\text { Library } \\
\text { - Admin } \\
\text { - Faculty } \\
\text { - } \text { Support Staff }\end{array}$ & $\begin{array}{l}0.002 \\
0.001 \\
0.001\end{array}$ & $\begin{array}{l}\text { Significant } \\
\text { Significant } \\
\text { Significant }\end{array}$ & $\begin{array}{l}\hat{\mathrm{Y}}=4.123-1.106 \text { Admin }-1.185 \text { Faculty }-0.703 \text { Support } \\
\text { Each category has a significant effect to the perception which } \\
\text { means there are differences in the perceptions of each category. }\end{array}$ \\
\hline $\begin{array}{l}\text { Laboratory } \\
\text { - Admin } \\
\text { - } \text { Faculty } \\
\text { - } \text { Support Staff }\end{array}$ & $\begin{array}{l}0.031 \\
0.000 \\
0.000\end{array}$ & $\begin{array}{l}\text { Significant } \\
\text { Significant } \\
\text { Significant }\end{array}$ & $\begin{array}{l}\hat{\mathrm{Y}}=3.965-0.735 \text { Admin }-1.365 \text { Faculty }-0.722 \text { Support } \\
\text { Each category has a significant effect to the perception which } \\
\text { means there are differences in the perceptions of each category. }\end{array}$ \\
\hline $\begin{array}{l}\text { Office, Function Rooms } \\
\text { - Admin } \\
\text { - Faculty } \\
\text { - } \\
\text { Support Staff }\end{array}$ & $\begin{array}{l}0.152 \\
0.002 \\
0.000\end{array}$ & $\begin{array}{c}\text { Not Significant } \\
\text { Significant } \\
\text { Significant }\end{array}$ & $\begin{array}{l}\quad \hat{Y}=3.856-0.465 \text { Admin }-1.056 \text { Faculty }-0.706 \text { Support } \\
\text { Admin has no significant effect to the perception which means that } \\
\text { it has no differences in the perceptions of faculty or support staff. }\end{array}$ \\
\hline $\begin{array}{l}\text { Assembly, Athletic Facilities } \\
\text { - Admin } \\
\text { - Faculty } \\
\text { - Support Staff }\end{array}$ & $\begin{array}{l}0.002 \\
0.001 \\
0.000\end{array}$ & $\begin{array}{l}\text { Significant } \\
\text { Significant } \\
\text { Significant }\end{array}$ & $\begin{array}{l}\hat{\mathrm{Y}}=3.846-1.223 \text { Admin }-1.254 \text { Faculty }-0.804 \text { Support } \\
\text { Each category has a significant effect to the perception which } \\
\text { means there are differences in the perceptions of each category. }\end{array}$ \\
\hline $\begin{array}{l}\text { Clinics } \\
\text { - Admin } \\
\text { - Faculty } \\
\text { - } \text { Support Staff }\end{array}$ & $\begin{array}{l}0.009 \\
0.001 \\
0.000\end{array}$ & $\begin{array}{l}\text { Significant } \\
\text { Significant } \\
\text { Significant }\end{array}$ & $\begin{array}{l}\hat{Y}=4.031-0.944 \text { Admin }-1.3 \text { Faculty }-0.75 \text { Support } \\
\text { Each category has a significant effect to the perception which } \\
\text { means there are differences in the perceptions of each category. }\end{array}$ \\
\hline $\begin{array}{l}\text { Student Center } \\
\text { - } \text { Admin } \\
\text { - } \text { Faculty } \\
\text { - } \\
\text { Support Staff }\end{array}$ & $\begin{array}{l}0.074 \\
0.008 \\
0.000\end{array}$ & $\begin{array}{l}\text { Not Significant } \\
\text { Significant } \\
\text { Significant }\end{array}$ & $\begin{array}{l}\hat{\mathrm{Y}}=3.933-0.633 \text { Admin }-1.283 \text { Faculty }-0.763 \text { Support } \\
\text { Admin has no significant effect to the perception which means that } \\
\text { it has no differences in the perceptions of faculty or support staff. }\end{array}$ \\
\hline $\begin{array}{l}\text { Food Services } \\
\text { - Admin } \\
\text { - } \text { Faculty } \\
\text { - } \text { Support Staff }\end{array}$ & $\begin{array}{l}0.041 \\
0.028 \\
0.000\end{array}$ & $\begin{array}{l}\text { Significant } \\
\text { Significant } \\
\text { Significant }\end{array}$ & $\begin{array}{c}\hat{\mathrm{Y}}=3.933-0.844 \text { Admin }-0.911 \text { Faculty }-0.88 \text { Support } \\
\text { Each category has a significant effect to the perception which } \\
\text { means there are differences in the perceptions of each category. }\end{array}$ \\
\hline
\end{tabular}




\subsection{The Proposed Facility Management Policy Guide for the Bulacan State University}

The proposed facility management policy based on the assessment was developed. It is divided into six parts, namely; 1) Introduction, 2) Mission Statements, 3) Administration, 4) Jurisdiction, 5) Maintenance and 6) Operations. Administration includes policies on Budget, Policy Review and Control, Policy Statement and Utility System Management Plan. Jurisdiction, on the other hand, discusses policies on Automotive Shop, Heating, Ventilation \& Air Condition, Plumbing Shop, Paint Shop, Ground Shop and Electric Shop. Maintenance covers the Building Maintenance Program, Electrical Distribution, Emergency Electrical, Fire Alarm System, Fire Contractor, Fire Pumps and Valves, Fire/Smoke Walls and Floors, Preventive Maintenance, Refrigerants, Sprinkler and Vehicles. Finally, Operations discusses topics on policy for Contractor Request, Estimating Work Order Request, Key Control, Tool Control, Utility Interruption and Work Request.

\section{Conclusion}

On the basis of the findings, the study concludes that there are significant differences among the perceptions of the administrators, faculty members and support staff on the extent of monitoring and evaluation of physical facilities at the Bulacan State University.

\section{Recommendations}

On the basis of the significant findings and conclusions of this study, the following are posited as the recommendations:

1) The school should have orientation regarding awareness and maintenance of physical facilities of the University for both students and teachers to participate and to give them an enhanced level of awareness on how to care and use properly the said facilities.

2) That further studies on this topic be done in other SUCs in the region in order to give them invaluable insights regarding physical facility management in their respective institutions.

3) Finally, it is also recommended that the proposed Facility Management Policy Guide for the Bulacan State University is implemented to improve all the stakeholders on the extent of monitoring and evaluation of physical facilities in the University in terms of the following physical facilities, namely, campus, buildings, classrooms, library, laboratory, offices, staff and function rooms, assembly and athletic facilities, medical and dental clinic, student center, and food services/canteen.

\section{References}

[1] https://en.wikipedia.org/wiki/Bulacan_State_University

[2] https://en.wikipedia.org/wiki/Bulacan State University

[3] Best, J.W. and Kahn, J.V. (1998) Research in Education. 8th Edition, Butler University, Emeritus, University of Illinois, Chicago.

[4] www.ehs.iastate.edu

[5] http://www.wbdg.org/design/ensure_health.php

[6] http://www.ncbi.nlm.nih.gov/books/NBK55867/

[7] Asiabaka, I.P. (2008) The Need for Effective Facility Management in Schools in Nigeria, Department of Education Foundations and Administration, Faculty of Education, Imo State University, Owerri, Nigeria. New York Science Journal. http://www.sciencepub.org

[8] Asiabaka, I.P. (2008) The Need for Effective Facility Management in Schools in Nigeria, Department of Education Foundations and Administration, Faculty of Education, Imo State University, Owerri, Nigeria. New York Science Journal. http://www.sciencepub.org 